\title{
Virtual Judgment Proofing: A Rejoinder
}

\author{
Lynn M. LoPucki ${ }^{\dagger}$
}

In the future, and to the greatest extent possible, Sara Lee will be a virtual company, putting its virtual name on things it doesn't make.'

Before Manville, big businesses paid their tort liabilities.? In its 1982 bankruptcy reorganization, Manville's investors lost nearly the entire value of the company-over $\$ 2$ billion-to tort creditors. The damages from Union Carbide's 1984 release of toxic chemicals that killed 4000 people in Bhopal, India were estimated in the billions of dollars before the courts came to Union Carbide's rescue. ${ }^{3}$ The following year, A.H. Robins took a $\$ 2.5$ billion hit from Dalkon Shield claimants, ${ }^{4}$ and a Texas jury awarded Pennzoil \$1I billion in a tort case against Texaco. ${ }^{5}$ In 1989, the Exxon Valdez spilled oil that led to over $\$ 9$ billion in judgments against Exxon. ${ }^{6}$ Now, the tobacco companies' tort liabilities are estimated in the hundreds of billions. ${ }^{7}$ These cases mark a historic shift in the nature and magnitude of liability.

In Corporate Judgment Proofing, ${ }^{8}$ Professor James J. White argues-and indeed claims to have proven empirically - that big businesses have erected no legal defenses in response. To do so, he argues, would have been futile. The companies' lenders and trading partners would not have permitted it.' The courts would have disregarded limited liability and deemed the companies'

† A. Robert Noll Professor of Law, Cornell Law School, Visitung Professor of Law, Harvard Law School. I thank David Chamy, Ted Eisenberg. Frances Foster. Elizabeth Wamen. and Walter Weyrauch for comments on earlier drafts, and Ronald Mann for assistance in refining the arguments regarding contract creditors.

1. Roger Lowenstein, Remember When Compantes Sfade Thungs?. WALL ST. J., Sept. 18, 1997, at Cl.

2. See, e.g., Note, The Manville Bankruptcy: Treating Mass Tor Clauns in Chupter II Proceedings. 96 HARV. L. REV. 1121, 1121 (1983) ("Although Manville and UNR Industnes are the first such apparently healthy corporations to file chapter 11 petitions in the face of massive ton elasms, manufacturers in a variety of industries that face similar liability could follow sutt.").

3. See Union Carbide Sells Plant in India That Was Sise of Industrual Disaster. AP. Sept. 9. 1994. available in 1994 WL 10137800.

4. See Emily Couric, The A.H. Robins Saga. A.B.A. J.. July 1986. al 56.

5. See Pennzoil Co. v. Texaco, 481 U.S. 1, 7 n.5 (1987) (discussing the tnal court judgment)

6. See In re Exxon Valdez, 767 F. Supp. 1509 (D. Alaska 1991).

7. See John Schwartz \& Saundra Torty, Tobacco Firms Negonatmg Package Sethlement of Sults. WASH. POST, Apr. 17, 1997, at Al (discussing a settlement proposal capping tobacco firm ltability at $\$ 300$ billion).

8. James J. White, Corporate Judgment Proofing: A Response to Linn LoPuckis The Death of Liability, 107 YALE L.J. 1 (1998).

9. See id. at 1395-1399. 
every move a fraudulent conveyance. ${ }^{10}$ Public outrage and government retaliation would have followed."

The occasion for Professor White's observations is the publication of my article The Death of Liability in $1996 .^{12}$ In that article, I predicted that individuals and businesses of all sizes would increasingly defeat their liability by judgment proofing their operations. The legal structures by which they would accomplish that would have one thing in common: The entities engaging in activities that could potentially generate significant liabilities would not own substantial unencumbered assets. Ownership of assets would accumulate only in entities with little potential to generate liabilities. As a result, I predicted the American economy was evolving toward a future in which:

There will be entities that own things and entities that do things. Those that own things-the bankruptcy remote vehicles-will not do anything, lest they expose their assets to liability. Those that do things - the operating companies-will not own anything, lest their judgment creditors have something to attach. ${ }^{13}$

In this future, plaintiffs would no longer sue for money judgments because they could not collect. The liability system would no longer serve any purpose and would die.

White omits from his description of my thesis all mention of computerization-the driving force behind the death of liability ${ }^{14}$ - and instead strains to make judgment proofing by large corporations the issue. ${ }^{15}$ In his view, "Most individuals have always been judgment proof, and few private companies can cause sufficient statutory or tortious liability to cause a significant social problem."16 The judgment proofing of the remaining individuals and private companies in the American economy is "a problem of

10. See id. at 1405-1407.

11. See id. at 1411-1412.

12. Lynn M. LoPucki, The Death of Liability, 106 YALE L.J. 1 (1996).

13. Id. at 28.

14. Computerization only recently made it possible to divide the investment risks and rewards associated with a business in complex, nonintuitive ways, leading to trading in derivatives. Computcrization is now making it possible to address separately each of the variety of purposes served by the ownership of assets. In the modern public company, the ownership of unencumbered assets assures creditors of payment, provides liquidity, absorbs risk, stabilizes the business financially, reduces contracting and other transaction costs, makes the business an attractive place for managers to work, and qualifies the company to raise growth capital in financial markets. The perfection of new devices to address each of these needs will free the business of tomorrow from the need to own unencumbered assets and in doing so, free it from liability. For example, computerization can facilitate risk-absorbing mechanisms such as guarantecs, payment insurance, and letters of credit that insure payment to contractual stakeholders.

15. To achieve his focus, Professor White first argues that I "should be concerned principally with injuries caused by business enterprises, not with torts by individuals" because "[i]t is a rare individual who can cause enough personal injury or property damage to make it worth his while to escape liability." White. supra note 8, at 1366. As I stated in The Death of Liability, "Judgment proofing is less common among large businesses." LoPucki, supra note 12, at 19.

16. White, supra note 8 , at 1367. 
modest social consequence." 17 With this argument, Professor White essentially concedes my thesis with respect to individuals.

White has chosen his ground wisely, because the judgment proofing of individuals appears to be in rapid acceleration. The Death of Liability describes the decade-old boom in offshore "asset-protection trusts"-devices sited in offshore havens but widely promoted here as an effective means for Americans to render themselves judgment proof. 18 "Asset-protection trust" is merely a euphemism for "self-settled spendthrift trust." Self-settled spendthrift trusts are, in essence, private declarations by property owners that they will retain full use and control of their assets, but that their judgment creditors will not be able to reach them. Not surprisingly, the law in the United States has long been that self-settled spendthrift trusts are void as against public policy. ${ }^{19}$

As the offshore asset-protection trust industry prospered, U.S. banks and trust companies became envious. Six months after publication of The Death of Liability, Alaska became the first state to recognize self-seuled spendthrift trusts. ${ }^{20}$ Americans can now judgment proof themselves without transferring their money and the titles to their properties to strangers offshore. ${ }^{21}$ The situs provisions of the new law are tailored to make these trusts available, not just to residents of Alaska, but to residents of all states. Within a few months, Delaware became the second state to permit the establishment of self-settled spendthrift trusts. ${ }^{22}$ These laws mark a historic change in the policy of American jurisdictions toward judgment proofing.

\section{The Financial Data on Corporate Judgment Proofing}

By relying on Compustat data, ${ }^{23}$ Professor White narrows his attack to only the largest public companies. The move excludes from consideration over

17. Id. at 1367.

18. LoPucki, supra note 12 , at 32-38.

19. See Elena Many-Nelson, Offshore Asser Protecuon Trusts: Havmg Vour Cake and Eatung "t Tow. 47 RuTGERS L. REV. 11, 28-56 (1994).

20. See Alaska Trust Act. 1997 Alaska Sess. Liws A.L.S. ch. 6. $\$ 7$ (codified al ALASha STAt $\$$ 34.40.110 (Michie Supp. 1997)): see also Jonathan G. Blattmachr \& Howard M. Zantshy. Estute Plannung with Alaska Trusts, PROBATE PRAC. Sept. 1997, at I. I "The new Alaska rule is similar to that adopted in many foreign jurisdictions in that the interest of the grantor is not subject to the elaums of the grantor's creditors unless the transfer in trust was fraudulent.").

21. See Lynn Asinof, Protection of Offshore Trusts Comes Onshore in Two States, WaLS ST J. July 23, 1997, at Cl.

22. See Qualified Dispositions in Trust Act. 71 Del. Laws A.L.S. ch. 159 (1997) (10 be codified at DEL. CODE ANN. tit. I2, $\$ \$ 3570-3576$ ). Delaware's product is markedly infenor for judgment-prooting purposes because the spendihrift features of the law are not intended to be effecuve against tort creditor See Blattmachr \& Zaritsky, supra note 20, at 5.

23. See White, supra note 8 , at 1370 n.38. 
$99.9 \%$ of the firms in the American economy. ${ }^{24}$ But even with respect to those companies, none of his Compustat data contradicts my thesis.

\section{A. Secured Debt to Assets}

White claims to disprove the thesis that public companies increasingly use secured debt strategies. ${ }^{25}$ That was not, however, a thesis I have ever advanced. As I stated in The Death of Liability, "Secured debt strategies . . . are employed primarily by small, relatively uncreditworthy businesses,"26 and "when large businesses do judgment proof, they use different techniques," which I identified as parent-subsidiary and asset-securitization strategies. ${ }^{28}$ White admits that he is unable to test empirically for parent-subsidiary judgment proofing ${ }^{29}$ and he has not responded at all to the data I presented on asset securitization. ${ }^{30}$

\section{B. Assets to Liabilities}

For similar reasons, White's data regarding asset-to-liability ratios add little or nothing. As he himself observes, the Securities and Exchange Commission (SEC) data on which Compustat is based are consolidated for all members of the corporate group. ${ }^{31}$ That data shows the aggregate assets and aggregate liabilities for the group, but does not show the assets or liabilities of any member of the group. If a tort-risk-generating subsidiary had assets of $\$ 1$ million, while its non-risk-generating parent had assets of $\$ 99$ million, the financial data on this group would show assets of $\$ 100$ million. Assuming that the courts would respect the subsidiary's formal status as a separate entity, this corporate group would have only $\$ 1$ million in assets exposed to liability. Yet,

24. The Compustat database contains data on only about 7000 to 9000 companies. Those companies were selected by Standard \& Poors, the compilers of Compustat, for their prominence from the approximately 16,000 public companies filing with the Securities and Exchange Commission. Dun \& Bradstreet reports on approximately 10 million companies. See DUN \& BRADSTREET, YOUR MEMBERSHIP JUST GOT MORE MEMORABLE (1997). White attempts to compensate for this large-company bias by selecting the "200 smallest" companies in Compustat. White, supra note 8, at 1372. But by rerunning White's query, I determined that in 1996, the largest of the "200 smallest" as defined by Professor White was Smith Corona Corp., with assets of $\$ 83$ million. White's reference to such companies as "small companies" is misleading. Id. at 1372.

25. See White, supra note 8 , at 1374.

26. LoPucki, supra note 12 , at 14 .

27. Id. at 19 .

28. See id. at 19-30. Public companies do not use secured financing because they can accomplish precisely the same thing using a parent-subsidiary strategy with the valuable assets and the preferred creditors in the subsidiary. See id. at 20-21.

29. See White, supra note 8 , at 1388.

30. See LoPucki, supra note 12 , at 24 (illustrating the rapid rise in securitized debt as a percentage of all consumer debt).

31. See White, supra note 8 , at 1388 \& n.97. 
if the group had no debt, White's criteria would recommend this company as a perfect example of the absence of judgment proofing $-\$ 100$ million in assets and no liabilities.

Nor will the effects of asset securitization show up in the asset-to-liability ratios of judgment-proofed companies. In The Death of Liability. I used the example of a hypothetical firm that I called "Zero Asset Exxon":

Through a series of asset securitizations, Exxon Corporation disposes of all of its assets. As the cash from these transactions becomes available, Exxon distributes the cash to its shareholders in the form of dividends, leaving the company with neither assets nor liabilities. . . . Because Exxon contracts to continue use of each asset even as Exxon sells it, the operations of Zero-Asset Exxon remain exactly as they were when it was a multibillion dollar company. But . . Z Zero-Asset Exxon is now judgment proof. ${ }^{32}$

Zero-Asset Exxon has neither assets nor liabilities, so it has no asset-lo-liability ratio. But it can easily achieve one-whatever ratio the judgment proofer pleases-simply by acquiring nominal assets and even more nominal liabilities. For example, if Zero-Asset Exxon acquired $\$ 100,000$ in assets and $\$ 20,000$ in debt, it would have a healthy asset-to-liability ratio of five to one. But for all practical purposes, it would remain judgment proof. The point is that asset-toliability ratios can tell us little or nothing about the kinds of judgment proofing I predicted in The Death of Liability.

Nor, perhaps, can any Compustat data alone. Public companies are not simply private companies that have registered with the SEC; they are public for a specific purpose-to raise capital in public markets. To enter those markets and remain viable in them, the companies are expected to maintain certain financial ratios. The public company that judgment proofs itself with secured debt does not achieve the expected ratios. That does not mean, however, that the public company simply absorbs whatever liability is associated with the industry in which it is engaged. The public company can use an inverted parent-subsidiary strategy that is the equivalent of secured debt, ${ }^{33}$ or can cause the liability to be generated in an independent entity that is unable to pay it. ${ }^{34}$

32. LoPucki, supra note 12 , at 26.

33. See id. at 20-21.

34. For example, when governments imposed mulubilion dollar liability on orl shupping. the reaction of some large oil companes was to divest themselves of their shipping subsidiaries Ser Willtam $J$ Cook. An Easy Way out of This Mess, U.S. New'S \& WORLD REP.. June 25. 1990. at 14. 14 Ireporting a decision by the Royal Dutch/Shell Oil Company to ship otl to the Unted States on independent tankers "[r]ather than risk being stuck" with liabilities for cleaning up any possible spills). When asbestos proved unreasonably dangerous, the largest companies left the industry to smaller ones. See Asbestos Setrlement. CHI. TRIB., Apr. 11, 1992, at I (discussing Keene Corp.): Mamville Asbessas Bill Paud, S F ExAulier. March 8, 1991, at B5 (discussing Manville): Amy Dockser Mareus \& Susan C Faludı. U.S Confhct Claimed in Waste Cleanup, WALL ST. J., July 10. 1991, at B2 (discussing Fibreboard). The hability. 
Even if the public company must surrender a particular activity to separate, private owners, the public company can continue to profit from it. This has occurred, for example, with "independent" automobile dealerships, gas stations, and other kinds of franchises. ${ }^{35}$ The law has been remarkably tolerant. For example, in Mobil Oil Corp. v. Bransford, ${ }^{36}$ the plaintiff was assaulted in a Mobil Mini Mart by a station employee. Mobil was the owner of the property, its products were sold in the Mobil Mini Mart, its contract with its franchisee required that the franchisee display Mobil's logos, its franchisee did in fact display them, and Mobil sent its representatives to the station to provide various support services. The employee was wearing the Mobil logo on his clothing when he attacked the plaintiff. Noting that the franchise agreement referred to the franchisee as an "independent businessman," however, the Supreme Court of Florida entered summary judgment in favor of Mobil. ${ }^{37}$ In effect, the court ruled that a franchisor cannot be held liable for the torts of its franchisee. Thus, public companies can divest themselves of liabilities simply by franchising the liability-generating aspects of their businesses.

The comparative advantages of public companies in raising capital and private companies in judgment proofing suggest that public and private companies may find it advantageous to work together. That is, public companies will raise the capital and own the assets that are deployed by private "partners." Such "partnerships"-in the form of franchisor-franchisee, lessor-lessee, or lender-borrower-may completely frustrate the liability system without the judgment proofing of any public companies. ${ }^{38}$ These facts cast doubt on White's belief that "data from private companies would be no different." 39

\section{The Bankruptcy Data}

Because trustees in bankruptcy cases have essentially the same rights to

generating activities have continued, but the companies continuing them have fewer assets and so have fewer assets at risk. For the system as a whole, the effect of divestiture is identical to judgment proofing.

35. See, e.g., Murphy v. Holiday Inns, Inc., 219 S.E.2d 874 (Va. 1975) (holding that the use of the licensor's name on a motel did not subject the licensor to liability).

36. 648 So. $2 d 119$ (Fla. 1995).

37. Id. at 121 .

38. For an example of such a "partnership," see the discussion of Rockefeller Center Properties infra notes $60-63$ and accompanying text.

39. White, supra note 8, at 1412. Empirical research on the financial structure of corporations is bascd almost entirely on public company data. No source of data on private companies is readily available. There is reason to believe, however, that private companies are different. In our empirical study of the bankruptcy reorganization of large publicly held companies, Professor William Whitford and I found that when a single shareholder owned a clearly controlling interest of an insolvent company, management continued to represent the interests of shareholders. The same was not true of comporations with widely dispersed shareholdings. See Lynn M. LoPucki \& William C. Whitford, Corporate Governance in the Bunkruptcy Reorganization of Large, Publicly Held Companies, 141 U. PA. L. REv. 669, 742-47 (1993). 
assets as do judgment creditors, ${ }^{40}$ the amounts recovered by trustees are indicative of the amounts available to judgment creditors. In The Death of Liability, I presented data showing that the percentage of no-asset bankruptcy estates-that is, the percentage of debtors fully judgment proof at the moment of bankruptcy filing-increased from less than $50 \%$ in the 1920 s to $95 \%$ in 1991 and 1992.41

Apparently having forgotten that The Death of Liability was about personal and corporate judgment proofing, White charges that I "distort] the data on bankruptcy by drawing inferences about judgment proofing from data compiled mostly from personal bankruptcies."42 White then altempts to dismiss the increase in the proportion of no asset estates as resulting merely from an increase in the proportion of nonbusiness bankruptcies from $87 \%$ in 1980 to over $95 \%$ in $1996 .{ }^{43}$ A historical quirk in the data, however, makes it possible to demonstrate that White's dismissal is unwarranted. The increase in the proportion of nonbusiness bankruptcies has not been relentless over time. That proportion was at $92 \%$ for a period in the late 1960s, " declined thereafter, and again reached $92 \%$ in 1991-1992--the years covered by the General Accounting Office study that presents the only data point on bankruptcy dividends since $1976 .{ }^{45}$ Thus, we have data on the recoveries of bankruptcy trustees in two periods, separated by twenty-five years, in which the proportions of business and nonbusiness bankruptcies were virtually identical. In both years of the earlier period-1967 and 1968-unsecured creditors received dividends in $12 \%$ and $13 \%$ of liquidating bankruptcies. ${ }^{36}$ In the later period-1991-1992-they received dividends in only $3 \%$ of liquidating bankruptcies. ${ }^{47}$ Whatever may account for that decline in recoveries, it was not merely a decline in the proportion of business bankruptcies.

40. See II U.S.C. $\$ 544(a)(1)-(2)(1994)$ (giving the tnustee the nghts of an Ideal judgment lien creditor).

41. See LoPucki, supra note 12 , at 18.

42. White, supro note 8 , at 1370 n.37 (ctation omitied).

43. See id. at 1379.

44. See AdMINISTRATIVE OFFICE OF THE U.S. COLRTS. TABLES OF BANKRL PTCY STATISTICS 5 (1978) [hereinafter TABLES OF BANKRUPTCY STATISTICS) (reponting proportions of $91.5 \%$ for cases filed in 1966 and $92.0 \%$ for cases filed in 1967).

45. See American Bankruptcy Institute, U.S. Bunkruptcr. Filungs 1980.1996 (Business. Nun-Bustiess. Total) (visited Dec. 8, 1997) <http://w'w'abuworld.org/stals/980annual.html> (reporting proportuons of 91.72\% for cases filed in 1990 and $92.42 \%$ for cascs filed in 1991). Filing data from the year pnor to the closing data is used because the modal tume from filing to closing is one year

46. See TABLES OF BANKRUPTCY STATISTICS. supra note 44. at 9 (countung. for 1967. 19.14t asset cases, 22,371 nominal assel cases, and 118,641 no assel cases, and for 1968, 21.360 assel cascs, 24,330 nominal asset cases, and 118,716 no asset cases). As with the 1990s data. filing data from the year pnor to the closing data is used because the modal ame from filing to closing is one year. See $U S$ GEN accounting Office, Case ReCeipts PaId to CRedtors and Professionals 9 ( $19 \%$ ) (itereinafter GaO REPORT].

47. See TABLES OF BANKRUPTCY STATISTICS. supra note Hi, at 5 
None of Professor White's alternative explanations plausibly explains the precipitous decline in bankruptcy payouts. ${ }^{48}$ The best remaining explanation is that the drafters of the Uniform Commercial Code were successful in their effort to reduce the costs and increase the reliability of security interests. Debtors encumbered more of their assets, leaving less for potential judgment creditors.

\section{Insurance}

Professor White admits that his argument from the insurance data rests on the assumption that "the [liability] losses generated by American business are more or less proportional to business activity (as measured by GDP)."49 Yet the fifteen-year period he examines includes the "litigation explosion" of the 1980 s-a period of rapid increase in environmental, products, and other kinds

48. Professor White offers four other explanations. None has merit. First, White suggests a possible increase in business losses in Chapter 11 cases. Without citing any evidence, Professor White asserts that current bankruptcy reorganization law is overly permissive, allowing debtors to lose in continuing operations the assets that would otherwise have been paid to unsecured creditors. See White, supra notc 8, at 1379 n.54. What evidence exists suggests the contrary. See, e.g., Theodore Eisenberg \& Stcphan Sundgren, Is Chapter II Too Favorable to Debtors? Evidence from Abroad, 82 CoRNELL L. REv. (forthcoming March 1998) (suggesting Chapter 11 yields a net gain to unsecured creditors). Even if White's assertion were true, it could not account for any substantial portion of the decline in the proportion of dividend-paying liquidations, because Chapter 11 cases were only about $2.8 \%$ of the bankruptcy cases filed in the relevant years. See NEW GENERATION RESEARCH, INC., THE BANKRUPTCY YEARBOOK \& ALMANAC 32 (1997) (reporting that 17,684 of the 613,465 cases filed in 1988 were under Chapter 11 and 18,281 of the 679,461 cases filed in 1989 were under Chapter 11). Cases filed two years before 1991-1992 are used because most of the asset bankruptcies reported in the 1991-1992 data were cases pending between one and three years. See GAO REPORT, supra note 46 , at 44.

Second, White imagines a possible increase in the expenses of bankruptcy administration. See White, supra note 8, at 1379 n.54. Professor White's argument is contrary to the data. In 1991-1992, only 5\% of bankruptcy estates had any assets in them at all from which expenses of administration could be paid. See GAO REPORT, supra note 46, at 1-2. The corresponding figures for the years 1940 to the end of record keeping in 1977 , were between $24 \%$ and $35 \%$. See TABLES OF BANKRUPTCY STATISTICS, supru note 44 , at 5 (providing data for the years from 1940 to 1977). Had no expenses of administration been paid at all, unsecured creditors would thus have received dividends of between $24 \%$ and $35 \%$ of bankruptcy cases from 1940 to 1977 , while that was true of only $5 \%$ of bankruptcy cases in 1991-1992. See LoPucki, stipra note 12, at 18. Therefore, the possible increase in expenses of administration Professor White hypothesizes cannot explain the precipitous decline in bankruptcy payouts.

Third, White considers a possible change in the timing of bankruptcy filings. He observes that if companies declared Chapter 11 early in their financial difficulties under one regime and later under another, "the distribution to creditors would be different under the two regimes." White, supra note 8, at 1379 n.54. The trouble with his argument is that in historical context, it cuts the wrong way. Today's debtors are quicker, rather than slower, to file bankruptcy. Delay in filing bankruptcy results in reductions, not increases, in the amounts of assets available to unsecured creditors. Thus, if Professor White's argument were correct, bankruptcy dividends would be higher today rather than lower, as observed.

Fourth, White argues that bankruptcy and state exemptions increased in 1978 and 1994. See id. ut 1380. The simple answer to the doubling of exemption amounts in 1994 is that it occurred after the 1926 to 1992 increase in judgment proofing, and hence cannot possibly explain it. By the first data point after the 1978 increase in federal personal exemptions, 1991-1992, some 39 of the 48 states had exercised their right to opt out of those changes, see ELIZABETH WARREN \& JAY LAWRENCE WESTBROOK, THE LAW OF DEBTORS AND CREDITORS 226-27 (1991), and the dollar amounts had been severely eroded by inflution. Many states increased their exemption amounts from 1976 to 1992, but White offers no evidence that the increases exceeded inflation.

49. White, supra note 8 , at 1381 . 
of commercial liability, as well as the birth of the "mass tort." Not only did the number of commercial tor cases increase at rates well in excess of gross domestic product (GDP), ${ }^{\mathrm{s}}$ the verdicts in those cases also increased at rates in excess of $\mathrm{GDP},{ }^{52}$ causing total commercial tor liability to increase geometrically. Only automobile liability-a category Professor White excludes from his data-lagged behind GDP. ${ }^{53}$ The more plausible explanation for White's data is that the aggregate liability imposed on American businesses increased at a rate considerably more rapid than GDP growth from 1981 to 1996, but insurance companies paid a considerably lower proportion of those claims. The erosions in insurance coverage during that period were so large they nearly offset the entire litigation explosion. ${ }^{\text {st }}$

\section{E. Subsidiaries}

In The Death of Liability; I defined judgment proofing to include any strategy that had the effect of denying satisfaction of a plaintiff's judgment." My definition includes "soft" judgment proofing that merely limits liability along with "hard" judgment proofing that "aims at denying all recovery to every plaintiff" because both externalize at least a portion of the cost of a company's economic activity. ${ }^{56}$

Rather than accept that every use of limited liability is "judgment proofing" because it defeats judgments, actual or potential. White redefines the

50. See Richard A. Seltzer, Punitive Damages in Mass Tor Lungahon. 52 FordHAM L Rt:V 37 (1983) ("Mass ton litigation in the 1980's has reached unprecedented levels").

51. See, e.g., Patricia Danzon. New Evidence on thit Freqt ency avo Stibrttr of Mlidical MALPRACTICE CLAIMS at vii (1986) (finding that clam frequency per physician gres at ruughly $10 \%$ per year from 1975 to 1984). Professor White cites Deborah R Hensler. Trends in Torn Lutgatum Fundenys from the Institute for Civil Justice's Research. 48 Ono ST L.J. 479 (1987). for the proposition that thete was a five-fold increase in product liability suts from 1975 to 1985 See Whate. stupru note 8 , at 1367 n 22

52. See DANZON, supra note 51. at vit (finding that the al erage payment per clum aganst physucians

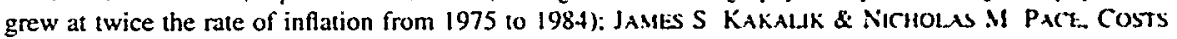
AND COMPENSATION PAID IN TORT LITIGATION 15 (1986) (finding that the aserage annual rate of grow th in total expenditures, nationwide, to compensate tor clams. excluding transitcion costs. from 1981 to 1985. was about $12 \%$ for automobile accident clams and about $17 \%$ for non-automobile clamms. while the Consumer Price Index grew at about 7\%): Theodore Eisenberg \& James A Henderson. Jr. Imstele the Qutet Revolution in Products Liability, 39 UCLA L. REv. 731. 76-65. 767 (1992) (show ing increases in products liability awards from the early to late 1980s, measured in constant dollars).

53. See Hensler, supra note 51, at 482 (reporing that "|a]utomobile cases are characterized by stability; products liability, malpractice, and other non-auto cases are growing at a substantal rate")

54. The "growth of insured losses incurred" marches relentlessly upward on Whate's graph only because he cuts off at 1995. See White. supra note 8. at 1381 For example, the 1996 medical malpractice data show a decline in losses covered, not just as a percentage of GDP. but also in absolute dollar amount See A.M. Best CO., Best's aggregates and Averages. Property-Cast altr 164-65 (1997) [hereinafter BEST'S AGGREGATES]. This trend reversil is corroborated by dala on the limits of labalaty insurance purchased in 1996. See MARSH \& MCCLENAAN. SI RVEY OF LIABIL.TY LISIrTS PL RCHASED BY MARSH \& MCLENNAN CLIENTS 3 (1996) (showing a decrease dunng the 1995 calendar year in the average limits of liability insurance purchased by the 397 Marsh \& McLennin clienis with annual revenues betueen $\$ 500$ million and $\$ 10$ billion).

55. See LoPucki, supra note 1 , at 4 n.4.

56. Id. at 47 . 
term. Under his definition, an entity is judgment proof "only if the managers knowingly operate with a sum of free assets and insurance coverage that is less than the present value of the firm's expected liabilities." 57 White himself suggests the example of a firm whose operations pose a one-in-ten-thousand risk of inflicting a catastrophe in ten years. Merely adding dollar amounts to his example exposes the extremity of his position. If the firm posed a one-inten-thousand risk of inflicting $\$ 100$ million in damages and decided to operate with no assets and only $\$ 10,000$ in liability insurance, White would say that the firm was not judgment proof and the managers had not engaged in judgment proofing. Under White's formula, Union Carbide, Texaco, and Exxon could have deliberately structured their companies to limit their liability to under $1 \%$ of the damage they inflicted, without having engaged in "judgment proofing."

The fallacy of White's position becomes apparent when we consider a world in which there are 10,000 such companies. In the aggregate, these firms would be expected to cause one $\$ 100$ million catastrophe over the ten year period. If each firm maintained only the minimum insurance White would require to avoid "judgment proofing," the total insurance available to compensate for that catastrophe would be $\$ 10,000$. In that world, $99.99 \%$ of tort liability would go uncompensated even though nobody was guilty of "judgment proofing."

Redefining judgment proofing will not prevent strategies of the kind described here from undermining and killing the liability system. The liability system will not remain intact until the last business disposes of its last asset. It will collapse soon after the public realizes that it is ineffective-that businesses can manipulate the amounts of their legal liabilities simply by shuffling a few papers at the appropriate time and that substantial numbers of businesses are doing so.

\section{How COMMERCIAL Firms Will BeCome Judgment PROOF}

\section{A. Contracting Parties Will Not Protect the Tort Creditors}

At a number of places in his essay, White makes variants of a single, basic argument: Debtors cannot judgment proof their businesses because third parties who contract with them will require, as a condition of that contracting, that the debtor purchase liability insurance or maintain unencumbered assets. ${ }^{58} \mathrm{He}$ is correct that some lenders currently require that debtors maintain specified ratios of assets to liabilities, some hospitals currently require that affiliated doctors maintain liability insurance, and some unions currently concern

57. White, supra note 8 , at 1363 n.2.

58. See White, supra note 8, at 1369, 1395-1396, 1408. 
themselves with acts that affect the future solvency of the company. In each case, the third party assures the availability of unencumbered assets or insurance to which future tort creditors can look for their recoveries.

Means exist, however, by which contract creditors can protect themselves without protecting tort creditors. The relative costs of these alternatives are declining as computerization brings down the cost of complex contracting." These alternatives will soon outstrip conventional forms because all parties to the alternative contracts can share in the savings achieved by externalizing the liability of one or more of them. No value need be "wasted" by permitting it to spill over in favor of the unrepresented future tort creditors.

\section{Contracting Parties}

The typical bank lender to a small business does not require the owner to contribute sufficient equity to the corporation to assure repayment of the loan. Instead, the typical bank lender protects itself by obtaining the personal guarantees of the owners of the debtor corporation, leaving other creditors of the corporation-including the future tort creditors-to fend for themselves. If the corporation is large and its shares widely dispersed, securing the personal guarantees of the owners may be impractical. Even in that situation, though, the corporation can assure contracting parties of payment through the guarantee of another corporation in the group, the purchase of a letter of credit in favor of the contracting party, or the purchase of payment insurance.

The financing of Rockefeller Center prior to its Chapter 11 reorganization in May 1995 illustrates the use of these techniques. The land and buildings constituting Rockefeller Center were owned by two partnerships, referred to collectively as Rockefeller Center Properties (RCP). The partners were two private corporations, Rockefeller Group, Inc. and Rockefeller Center Music Hall Productions, Inc., that were in turn owned by unnamed members of the Rockefeller family and Mitsubishi Estate Company, Inc. Rockefeller Center was appraised at $\$ 1.25$ billion in 1994. The ownership structure was hard judgment proofed by a mortgage in the amount of approximately $\$ 1.3$ billion in favor of Rockefeller Center Properties, Inc. (RCPI), a public corporation that apparently was created to and did deal at arm's length with RCP. ${ }^{60}$ If White's theory were correct, RCPI would have required that RCP maintain a cushion of equity and thereby have served as a "guardian of corporate solvency." Instead, RCPI required that RCP furnish a letter of credit in the amount of $\$ 50$

59. See LoPucki, supra note 12. al 47-51.

60. See Rockefeller Ctr. Properties, Inc.. Foris I0-K for thie Year ENdisg De:cemibr 31. 1995, at 6 (1996). At least as of that filing. RCPI had no interest in Rockefeller Group. Inc See ul at 12

61. See White, supra note 8, at 1412 ("“[C]ontract creditos and other guardians of corporate solvency may be even more watchful of private than of public companics") 
million-solely for the benefit of RCPI. ${ }^{62}$

Had portions of Rockefeller Center toppled into the streets of New York and caused billions of dollars in damages while this structure was in place, the judgment creditors probably could not have reached either the value of Rockefeller Center or the wealth of the Rockefeller family and the Mitsubishi Estate. Under the principle of subordination, ${ }^{63}$ the value of Rockefeller Center belonged first to the secured creditor that loaned money at arm's length; the Rockefeller family and Mitsubishi were protected by corporate limited liability.

In Compustat data, Rockefeller Center appears innocuous. The judgmentproof RCP was a private partnership owned by private corporations. None of these private corporations filed $10-\mathrm{K}$ forms, so none was included in Compustat. The traditionally financed mortgagee, RCPI, was a public corporation included in Compustat. It obtained its financing through a blend of secured debt, unsecured debt, and equity in proportions considered appropriate for public corporations. Because all of the liability involved in owning and operating Rockefeller Center was generated on the private side of this structure, and virtually all of the capital was contributed on the public side, the resulting structure was elegantly judgment proof. That structure demonstrates again the futility of trying to prove the absence of judgment proofing in the American economy with nothing but Compustat data.

\section{Contract-Required Insurance}

In The Death of Liability, I observed in passing that if a building construction contract were well-drafted, the subcontractor's ability to discharge its future tort liabilities in Chapter 11 could, from the standpoint of the contractor, be an adequate substitute for liability insurance. ${ }^{64}$ In reply, White states that he finds it hard "to imagine a world in which firms are judgment proof and Chapter 11 is less expensive and less stigmatizing than insurance. ${ }^{365}$ Yet the world White cannot imagine is, with respect to a large proportion of all liability, the world in which we live. Numerous businesses and individuals that could afford to insure against bankruptcy-threatening risks deliberately choose not to. In the past, they have included the Manville Corp. for risk in excess of $\$ 700$ million, Texaco for the entire risk of tortious interference, and the tobacco industry for products liability risk. ${ }^{66}$

White correctly points out that the costs of Chapter 11 , direct and indirect, are high. For large public corporations, they are probably in excess of $10 \%$ of

62. See Rockefeller CTR. Properties, INC., supra note 60 , at 80.

63. See LoPucki, supra note 12 , at 11.

64. See id. at 76-77.

65. White, supra note 8 , at 1383.

66. See the sources cited in Lynn M. LoPucki, The Unsecured Creditor's Bargain, 80 VA. L. REv. 1887,1906 n.81 (1994). 
the value of the company. ${ }^{67}$ But White errs when he compares the cost of a Chapter 11 case with the cost of an insurance policy to decide whether externalizing one's liability through judgment proofing is less costly than paying one's liability through insurance. For every self-insuring company forced into Chapter 11, dozens or hundreds of self-insuring companies are not. Most self-insuring companies encounter only small amounts of tort liability, and pay it. Among those that encounter large tor liabilities, most will be able to settle in the shadow of bankruptcy without having to file. To compare the cost of Chapter 11 to the cost of insurance accurately, one must discount the cost of Chapter 11 for the probability Chapter 11 will actually be necessary. In a world in which every company is judgment proof, forcing a tort recovery will be impossible. Tort actions will be rare in such a world, and Chapter II filings rarer.

\section{Codefendants}

In arguing that potential codefendants will require that debtors carry liability insurance, White uses the example of a hospital, an anesthesiologist, and a surgeon who might be sued jointly for a botched operation. He concludes that the three will agree that the surgeon must insure. ${ }^{63}$

Though hospitals commonly impose such requirements today, that consequence too flows merely from the current costs of contracting as well as public and customer relations considerations. Absent those considerations, hospitals and doctors will tend to adopt the contracting scheme that minimizes their total costs, enabling them to divide the benefits among them. When contracting costs are low, the schemes that minimize total costs for the hospitals and doctors are ones that externalize their tort liability. Absent public and customer relations considerations, ${ }^{69}$ the hospital's lowest cost response is not to require the doctor to carry malpractice insurance. but to make the hospital's own operations judgment proof.

Even if the hospital cannot become judgment proof, the hospital will not require the physician to insure. To understand why, assume (1) that all physicians are judgment proof; (2) that no hospitals are judgment proof; (3) that all malpractice is committed by physicians: and (4) that for any incident

67. See Gregor Andrade \&: Steven N. Kaplan. How Costly Is Financtal (Not Economic) Distreas' Evidence from Highly Leveraged Transactions That Become Distressed 5 (July 1997) (unpublished manuscript, on file with author) (estimating the direet and indirect costs of financial distress at "an average of $10 \%$ with an upper bound of $24 \% ")$.

68. See White, supra note 8 , at 1407.

69. Despite such considerations. many hospitals and phystctans attempt to contract out of their malpractice liability through "releases" signed by their patıents. They encounter, however. only mixed success. See A.M. Swarthout. Annotation. Validin and Consirucrion of Contract Exemping Hospulul or Doctor from Liability for Negligence to Pattent, 6 A.L.R.3d 704 (1966). Judgment proofing is sull less likely to offend patients for the simple reason that the patients are less likely to know about it untul it is too late. 
of malpractice, the chance of being held liable is $80 \%$ for physicians and $40 \%$ for the hospitals. If the aggregate level of malpractice is $\$ 100$, the system will cost the responsible hospitals $\$ 40$ and judgment-proof physicians nothing. If the hospitals accept Professor White's suggestion to require the physicians to insure, the direct cost to physicians will be $\$ 80$ and the direct costs to hospitals will be zero.

But why would the hospitals impose $\$ 80$ of liability on their associated physicians in order to save only $\$ 40$ for themselves? Both hospitals and physicians would be better off in a relationship in which the hospitals waived the requirement of malpractice insurance in return for a payment of $\$ 60$. That scheme would cost the physicians only $\$ 60$. From that $\$ 60$, the hospital could pay the $\$ 40$ of liability unjustly imposed upon them, leaving the hospital with a "profit" of $\$ 20$.

Patients would likely favor this solution as well. In a full-insurance regime, they would be protected by $\$ 80$ in malpractice insurance. That $\$ 80$, however, would tend to be added to the cost of medical services and therefore to the costs of health insurance. Each patient would tend to pay his or her pro rata share of the $\$ 80$ cost of a full insurance regime. Most of that money would not be paid out to patients in benefits, but would be consumed in the process of determining fault. $^{70}$ Assuming that the quality of care would not be worse in a judgment-proof hospital, ${ }^{71}$ an individual patient would be better off going to a judgment-proof hospital and buying first-party insurance that would compensate the patient for bad results regardless of whether they were caused by malpractice. ${ }^{72}$

If first-party insurance combined with peer review is a more cost-effective solution to the malpractice problem than the liability system, why do so many hospitals still impose the liability system on their physicians? Perhaps because the law restricts the ability of the hospital, the physician, and the patient to contract out of the liability system directly. ${ }^{73}$ The indirect means of contracting out-becoming judgment proof-remain stigmatized. But, as I explained in The Death of Liability, that is merely a cultural preference that in the long run economic forces will overwhelm. ${ }^{74}$

70. For example, from 1987 to 1996, allocated and unallocated expense payments by insurers were about $38 \%$ of the total net paid on medical malpractice claims. See BEST'S AGGREGATES, supra note 54. at 165 (providing data forming the basis of this calculation). Probably, most plaintiffs also paid their attorneys percentages of the net recovery ranging from about $25 \%$ to $50 \%$.

71. Though radical-sounding, this assumption may be warranted because tort law causes the dangerous practices of "defensive medicine" and is generally regarded as an inefficient means for deterring wrongful conduct. See the sources cited in LoPucki, supra note 12, at 97 n.37. Alternative means of deterrence include the investigation and publication of peer reviews.

72. Cf. Mark Geistfeld, The Political Economy of Neocontractual Proposals for Products Liability Reform, 72 TEX. L. REv. 803, 811 (1994) ("The administrative costs of insurance delivered through tort law are vastly greater than the administrative costs of any first-party insurance regime.").

73. See Swarthout, supra note 69, at 705 (discussing the general rule that "persons may not contract against the effect of their own negligence").

74. See LoPucki, supra note 12, at 51-54. 


\section{B. Subsidiaries}

Professor White tries to persuade the reader that subsidiaries are used principally for purposes other than limiting liability: meeting the requirements of foreign investment laws. engaging in regulated businesses domestically, making every division head a CEO, and "segregating" a business to "more readily identify[] and calculat[e] its success or failure." "By choosing the example of Union Carbide, with $60 \%$ of its subsidiaries incorporated abroad, he conveys the impression that most subsidiaries are foreign. In fact, probably not more than about $20 \%$ of the subsidiaries of large U.S. publicly held companies are foreign. ${ }^{76}$ Probably, few subsidiaries conduct regulated businesses that require separate incorporation. Companies can award the title of "Chief Executive Officer" without separately incorporating the division and can segregate the business for accounting purposes without segregating it through separate incorporation. Limiting liability is widely understood to be the principal reason for the separate incorporation of subsidiaries."

Professor White is correct in thinking that the methods of parent-subsidiary judgment proofing he suggests would not be effective. He suggests that a parent corporation create a judgment-proof subsidiary by transferring the assets of a profitable but risky business to the subsidiary free and clear. ${ }^{7 x}$ The subsidiary would be subject to control by the parent and the parent would be "inevitably involved with the acts of [the] subsidiary in perpetuating mass torts." ${ }^{.79}$ If the subsidiary were profitable, it would be "routinely drain[ed] . . . of its assets" 80 by "distribut[ing the profits] upstream in the form of dividends" to the parent. ${ }^{81}$

I suspect that Professor White does not intend that we take his instructions for judgment proofing literally. More likely, he intends to assert that no matter how skillfully corporations judgment proof themselves, courts will protect the tort claimants and the liability system itself by disingenuously seizing upon some imagined flaw in the structure as an excuse for ignoring it. ${ }^{\text {sz }}$

75. White, supra note 8 , at 1391.

76. To estimate the percentage of foreign subsidiancs, I counled both the foreign and domestle subsidiaries in the 10 most recent groups to file under Chapter 11 of the Banhruptcy Code. selected on the following criteria: large companies that state the places of incorporation of their substitanes in their most recent 10-K listed and available in LEXIS. COMPNY Librar. ACCESS File (Jan 28. 1998) The ten groups had 333 subsidiaries, 58 (17\%) of which were foreign

77. See the sources cited in LoPuckı. supra note 12. 3t 21 n 78

78. See White, supra note 8, at 1391 ("If substantial assets are left in the subsidtan those assets will be available for tort claimants as well as othen "); $d$ at 1400 ("If the parent's assels anust be put into the subsidiary to do tts business. then those assets are at nut ")

79. Id. at 1400 .

80. Id.

81. Id. at 1391: see also id. at 1.403 ("To heep a prottuble substdian judgment proof requires that profits be distributed routinely to the parent as dividends so that the eamings are not avalable to tort and other claimants.").

82. Professor White suggests this disingenuousness theon most strongly in his destription of subsidiaries and affiliates in notorious tort cases In each of the cases he dexenbes, the judgment prooting 
Though such disingenuousness may correct egregious overreaching in obvious cases, it cannot substitute for rules that define overreaching and communicate that standard to judges. Professor White not only understands the need for bright line rules and certainty in commercial law, he is also their leading advocate. ${ }^{83}$ Commercial deal-making depends on the existence of simple, reliable rules, which judges and legal communities supply. ${ }^{84}$ The ad hoc system Professor White imagines does not exist and could not be made to work.

The judgment proofing that kills liability will be more sophisticated than White envisions. Its architects will put it in place before the subsidiary incurs any debt, rendering most of fraudulent conveyance law inapplicable. The subsidiary will not own the fixed assets used in the business; it will lease them from the parent at market rates. If the courts do not honor those leases, the next round of leases will be negotiated at arms' length with third-party owners. The parent will not control the subsidiary directly. Instead, a board of directors elected by the parent as shareholder will control it. If the board chooses to integrate the business of the subsidiary with that of the parent, it will do so by contract negotiated with the best interests of the subsidiary in mind. The parent will avoid involvement in the "grand torts" of the subsidiary. The subsidiary will hire and train its own employees. If economies of scale can be achieved by training employees of the subsidiary along with employees of other members of the corporate group, that training program will be in a separate subsidiary for whose malfeasance no other group member will be liable. No shipping subsidiary will inflict liability on its parent by carrying oil owned by the parent; the subsidiary will purchase the oil before loading it, and sell it only upon unloading it. The numerous transactions, within the corporate group and with its regular trading partners, will be fully documented and administered by the corporate group's computers.

Revenues will flow from risky subsidiaries by a variety of means. The bulk of the flow will be payment on the leased assets used in the business. One of those assets probably will be the trademark of the parent. ${ }^{85}$ Revenues will be used to pay for services provided by the parent, including the

failed because of some seemingly obvious error on the part of the parent corporation that future judgment proofers could easily avoid. See id. at 1391-1393.

83. See General Elec. Co. v. Halmar Distrib. (In re Halmar Distrib., Inc.), 968 F.2d 121, 125 (1st Cir. 1992) (quoting White's view that it is "'[b]etter to leave an occasional widow penniless by the harsh application of the law than to disrupt thousands of other transactions by injecting uncertainty and by encouraging swarms of potential litigants and their lawyers to challenge what would otherwise be clear and fair rules"” (quoting James J. White, in JAMES J. WhITE \& ROBERT S. SUMMERS, UNIFORM COMMERCIAL CODE $\S 26-20$, at 554-55 (3d ed. 1988))).

84. See Lynn M. LoPucki, Legal Culture, Legal Strategy, and the Law in Lawyers' Heads, 90 Nw. U. L. REv. 1498, 1516-21 (1996) (explaining the process by which legal communities render otherwise indeterminate law determinate in practice).

85. Cf. infra text accompanying note 120 (explaining how trademarks can be isolated from associuted liability). 
computerized information system that ties the corporate group together. Because the subsidiary owns nothing and pays as it goes for nearly everything it uses, the bills will be large and will tend automatically to approximate the revenues. Only in those periods when the revenues of the subsidiary greatly exceed the use value of the assets it employs will the subsidiary have to distribute revenues to its parent in the form of dividends. Simply by declaring those dividends publicly, the subsidiary can assure that four years after they are paid they are immune from attack under fraudulent transfer law. ${ }^{86}$

Professor White warns of the many practices that courts consider grounds for piercing the corporate veil. ${ }^{87}$ But the sophisticated judgment proofer need not engage in those practices. The only exception is that the judgment proofer must risk to some degree "inadequate capitalization." Judgment proofing accomplishes nothing unless it prevents the recovery of judgments. The uncollectibility of any judgment demonstrates that the business was in fact capitalized at a level inadequate to pay its debts, raising the possibility that a court could pierce the corporate veil and hold the parent liable on that ground.

The risk of such piercing is not great. The courts recognize that some inadequacy of capitalization to satisfy the corporation's liabilities must be tolerated. ${ }^{88}$ To hold otherwise would nullify the doctrine of corporate limited liability. In practice, the courts defer to corporate limited liability to such an extent that undercapitalization "[v]ery rarely, if at all" leads to disregard when other grounds are not present. ${ }^{89}$ Professor Robert Thompson reports that of the 1572 veil-piercing cases he studied, only 226 were tor cases, the court pierced in only seventy of them, ${ }^{90}$ and the cour cited undercapitalization as a ground for the decision in only nine. ${ }^{91}$ Both the law and practice remain as the Eighth Circuit recently described them:

The doctrine of limited liability is intended precisely to protect a parent corporation whose subsidiary goes broke. That is the whole purpose of the doctrine, and those who have the right to decide such

86. Under the Uniform Fraudulent Transfer Act. the statute of limititions on an action to recover a fraudulent transfer is no longer than "four years after the transfer was made" UNIF FRALDLLET TRANSFER ACT \$ 9, 7A U.L.A. 665 (1985); see also Uniled States 、 Neidorf. 522 F 2d 916 (9th Cir 1975) (holding that a six-year statute of limitations for the recosery of dividends fraudulently transferted to shareholders had run and that the dividends could not be recovered) The public announcement assures that the alternative period of limtlations, "one year after the trunsfer was or could reasonably have been discovered," will run earlier. UNIF. FRALDL'LEVT TRA SSFER ACT $\$ 9$.

87. See White, supra note 8 , at 1401-1402.

88. See, e.g., Alberto v. Diversified Group. Inc. 55 F.3d 201. 206-07 (5th Cir 1995) (holdıng that a corporation that left $\$ 58$ million of tort judgments aganst it unsitusfied was adequately capitalized because the purchasers of the corporation had invested \$2.4 million and agreed to insest an additional $\$ 2$ million)

89. ROBERT C. Clark, CORPORATE LAW 74 (1986)

90. See Robert B. Thompson. Piencing the Corporate Veal An Empurical Studs. 76 COR \E1. L REV 1036. 1058 (1991).

91. See id. at 1066 . 
questions, that is, legislatures, believe that the doctrine, on the whole, is socially reasonable and useful. ${ }^{92}$

\section{Fraudulent Conveyance Law}

White acknowledges that fraudulent conveyance laws are useless against judgment proofing by security interest or asset securitization. ${ }^{93} \mathrm{He}$ nevertheless finds comfort in the fact that "the corporation has not succeeded in hiding any assets: It still has the proceeds of the sale as assets."94 Professor White then proceeds to another topic, without responding to the point I made in The Death of Liability regarding those proceeds: The corporation is unlikely to retain the proceeds in cash. Either it will distribute them to shareholders, in which case they are beyond the reach of future tort creditors, or it will invest them in the business, in which case the size of the business, and presumably its capacity to generate liability, will be increased. The effect is a kind of soft judgment proofing, because the company's ratio of assets to potential liabilities has been reduced. ${ }^{95}$

\section{Government and Consumer Reaction}

In The Death of Liability, I argued that judgment proofing will prove impossible to eradicate because the principles on which it is based are so deeply rooted in American culture. ${ }^{96}$ Nevertheless, I recognized that the American public would not tolerate the open, deliberate, hard judgment proofing of the largest corporations. I concluded that to succeed, "the process of judgment proofing must appear to be something other than what it is" and suggested how that might occur. ${ }^{97}$

Current events in the tobacco industry illustrate the point. Professor White takes heart from the fact that Phillip Morris and RJR Nabisco, both facing monumental liabilities, have not spun off their food subsidiaries ${ }^{98}$ and is confident that "the tobacco divisions of B.A.T., R.J. Reynolds, or Phillip Morris are so richly endowed with assets that they would not be regarded as judgment proof by any standard measure." 99 In fact, there have already been five spinoffs in the tobacco industry, and both RJR Nabisco and Phillip Morris

92. Radaszewski v. Telecom Corp., 981 F.2d 305, 311 (8th Cir. 1992).

93. See White, supra note 8 , at 1405 .

94. Id.

95. See LoPucki, supra note 12 , at 26.

96. See id. at 8-13.

97. Id. at 54 .

98. See White, supra note 8, at 1406. After the Bhopal gas leak and before it seltled the case, Union Carbide went into a frenzy of spinoffs that some analysts considered judgment proofing. See Jonathan $\mathrm{P}$. Hicks, Carbide To Incorporate Its Three Key Businesses, N.Y. TIMES, June 24, 1988, at D4 (noting that "some analysts" saw the move as an attempt to insulate the operating units from Bhopal liability).

99. White, supra note 8, at 1406 n.161. 
have faced pressure from investors to spin off as well. ${ }^{100}$ Even though the only significant effect of these spinoffs would be to insulate better the assets of the parent companies from the liabilities of their subsidiaries, the media do not attribute the spinoff fever in the tobacco industry to judgment proofing. For example, the article on which Professor White relies for his confidence in the tobacco industry attributes the spinoff fever to the irrational and uninformed preferences of investors who continue to think that a liability "meltdown" is a real possibility even while the stock analysts assure them it is not. ${ }^{\text {tot }}$

The corporate groups of which the tobacco companies are parts have numerous subsidiaries. Even the tobacco subsidiaries are fragmented into numerous sub-subsidiaries. ${ }^{102}$ The financial disclosures required of the tobacco companies, like those of other public companies, are consolidated for the corporate group. From them, the reader cannot determine the assets or liabilities of any particular corporation within the group. Even if no tobacco subsidiary owned a single dollar of unencumbered assets, that would not necessarily be inconsistent with the public disclosures. The tobacco companies do disclose "identifiable assets" and revenues for the "tobacco segments" of their businesses, but there is no assurance that the tobacco segment assets are in the tobacco liability-generating subsidiaries. Moreover, the identifiable assets reported for the tobacco segments of the four major tobacco companies, plus the entire assets of the fifth, total only $\$ 36.1$ billion, less than $10 \%$ of the liabilities those companies have offered to pay. ${ }^{103}$ Both the national tobacco settlement and the settlements with the states release the parents of the tobacco

100. See Tobacco Giants Weigh Spmoffs To Boost Stod Prices. AP. Apr 16, 1994. atatlable in I904 WL 5189529.

101. See Suein L. Hwang \& Milo Geyelın. B.AT Mas Kich Tobacco Habut Despure Some Legal Insulation. WALL ST. J., Oct. 15. 1997, at B8 ("The truth is, holding companies currently aren't in the line of fire ...."), cited in White, supra note 8. at 1406 n 161. In fact. some plantiffs already sech to pierce the corporate veil of the tobacco subsidianes because they anticipate theis insolicncy Set. $c$ s. Arch v American Tobacco Co.. Civ. Act. No. 96-5903. 1997 U' S. Dist. LEXIS 8699 (E.D Pa June 16. 1997) (dismissing complaınt against parent B.A.T.); Mangland、 Phılıp Morns, Inc . No 96122017/CL211487. 1997 Md. LEXIS 85 (filed May 20, 1997) (namıng parents of five major tobacco compunies as defendants)

102. For example, RJR Nabisco reports 269 substdianes, 92 of which have R J Reynolds or RJR in their names. See RJR NABISCO HOLDINGS CORP. FORN 10-K POR THE YEAR ENDIAG DECEVIBLR 31. I\%\% exh.21 (1997), available in LEXIS, COMPNY Library. ACCESS File. Twenty-three of those are Deluw are corporations. See id.

103. The identifiable assets of the tobacco segments are Philip Moms. SI3 3 billion. see Pull ip

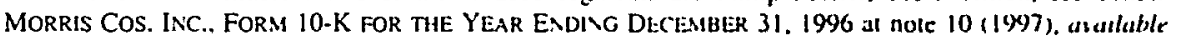
in LEXIS, COMPNY Library, ACCESS File: RJR Nabisco. $\$ 19$ billion, see RJR Nialisco Hol,DIscis CORP., FORM 10-K FOR THE YEAR ENDING DECENBER 31. 1996 at nole 14 (1997). as culuble in LEXIS. COMPNY Library, ACCESS File: Loew's, $\$ 7$ billion. see LOEwS CORP, FokM 10-K HOR tut: YeAR ENDING DECEMBER 31, 1996 at note 20 (1997), al allable in LEXIS. COMPNY Libran. ACCESS File.

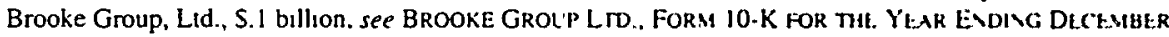
31, 1996 at note 18 (1997), aralable in LEXIS. COMPNY Library. ACCESS File The tilth. Broun \& Williamson Tobacco Company. has about $\$ 3$ billton in assets, but most or all of that may be encumbered See DUN'S BUSINESS RECORDS PLLS. BLSINESS MVORMATIOS REPORT OS Brows \& Willilisos TOBACCO CORP. 13 (1998). Dun \& Bradstreet reports Brown \& Williamson as having a net worth of about $\$ 683$ million, which Dun \& Bradstreet has for unexplanned reasons adjusted to a negaluve $\$ 366$ million See id. at 1, 12. The face amount of the tobacco settlement is $\$ 368.5$ billion payable over 25 yean See Mohammad Akhter, Expanding a Decall. Export Busmess. WaSH POST. Sept 11. 1997. at Als 
companies from liability, leaving only the tobacco subsidiaries liable. ${ }^{104}$ Approval of the settlement by Congress would be the linchpin in the most daring judgment-proofing scheme in history. ${ }^{105}$ The belief currently prevailing - that even as hundreds of millions of dollars in tort claims move toward trial the tobacco industry is not attempting to limit its exposure-has no sound basis in publicly available data. ${ }^{106}$ Thus does the judgment proofing of the tobacco industry appear to be something other than it is.

In the context of products like tobacco or asbestos, Professor White's argument that companies will not judgment proof out of concern for their image $^{107}$ reaches the level of the absurd. When Manville executives learned that their product might be deadly, they concealed that information and continued to sell asbestos for more than a decade while disposing of their asbestos holdings. ${ }^{108}$ The tobacco industry sells a product that contributes to the deaths of over 420,000 Americans a year. ${ }^{109}$ The industry continued to deny that its product was implicated in those deaths long after the American public ceased to believe it. ${ }^{110}$ Professor White would have us believe that the people who have done these things would shrink from judgment proofing out of fear for their good names. ${ }^{111}$

\section{E. Mandatory Insurance}

In The Death of Liability, I predicted political resistance to requiring insurance or bonds of all participants in the economy because such a

104. See Tobacco Settlement $\S \mathrm{VI}(b)(6)$ (visited June 25,1997 ) <http://www.usatoday.com/news/ smoke/smoke06.htm>, at 35 ("Obligation for annual payments responsibility only of entitics selling into domestic market."); Florida Settlement Agreement at II(C)(2) (Aug. 25, 1997) (visited Feb. 2, 1998) <hitp:// stic.neu.edu/FI/flsettle.htm> (providing that, upon final approval of the settlement by the court, "the State of Florida shall release and forever discharge all Defendants and their present and former parents, subsidiaries, divisions, affiliates, directors, employees, representatives, insurers, agents, attorneys, and distributors").

105. I have argued elsewhere that if the settlement is approved the tobacco companies are not so likely to use their judgment-proof status to avoid payment as they are to use it as leverage to extract further concessions from government. See Lynn M. LoPucki, Some Settlement, WASH. POST, Jan. 20, 1998, at A15.

106. Gary Black, widely regarded as the leading tobacco stock analyst, told me he does not have access to data indicating which assets are owned by which subsidiaries. Telephone Interview with Gary Black, Stock Analyst, Sanford, Bernstein (Nov. 18, 1997).

107. See White, supra note 8 , at 1411.

108. See Johns-Manville Sales Corp. v. Janssens, 463 So. 2 d 242 (Fla. Dist. Ct. App. 1984).

109. See Jon D. Hanson \& Kyle D. Logue, The Costs of Cigarettes: The Economic Case for Ex Post Incentive-Based Regulation, 107 YALE L.J. 1163, 1167 \& n.I (1998).

110. See id. at 1194-96.

111. Of course, they might shrink from judgment proofing at the same time that they did not shrink from intentional mass torts if the nonlegal sanctions for the former were greater than those for the latter. See David Chamy, Nonlegal Sanctions in Commercial Relationships, 104 HaRv. L. REv. 373 (1990) (discussing the importance of reputation and conscience as factors compelling contractual compliance). Judgment proofing is, however, highly technical, with the result that, as a practical matter, nonlegal sanctions are virtually nonexistent in the United States. As a test of this proposition, try to think of an instance in which judgment proofing was sanctioned nonlegally. Union Carbide is certainly an example in which it was not. 
requirement would bar the least-well-off segment of society from the traditional means of advancement: going into business for oneself. ${ }^{112}$ Based largely on the analogy to automobile insurance. I concluded that a mandatory insurance regime could require only low limits of insurance and would still remain difficult to enforce. ${ }^{113}$ Misunderstanding the enforcement problem. Professor White proposes that businesses be required to altach proof of insurance to their tax returns. ${ }^{114}$ To solve the problem of the low limits of coverage characteristic of nearly all mandatory insurance regimes, he proposes higher limits enforced by punitive premiums and criminal sanctions."1"s

But the problem with mandatory automobile liability insurance is not merely one of discovering violators. White is probably correct in thinking that a determined government could discover violators of a compulsory insurance law. But in California, nearly a third of the population violates the mandatory insurance law while their political representatives fight against particular enforcement mechanisms because they would be effective. ${ }^{116}$ The notion that one might need the approval of an insurance company to go into business for oneself is no more politically acceptable than the notion that one might need the approval of an insurance company to drive a car.

\section{VirTual Judgment Proofing}

The computerization of contracting is driven by forces much larger than the desire to avoid liability. For years, analysts have been predicting the advent of virtual companies - companies that literally consist of nothing but a web of contractual relationships. Instead of setting up its own data processing, "customer service, telemarketing, billing and collection, purchasing, employee training, accounting, publishing, legal administration and so on," the virtual company will "outsource" these functions-that is, contract with others to provide them:

Let's take, for an example, an airline. A handful of strategists put their heads together to decide where to fly and what to charge. As with many airlines these days, they lease their aircraft and hire flight and ground crews on contract. But then they hit the networks to find vendors for just about all other operations-passenger reservations, baggage tracking, accounting, aircraft loading, weather monitoring, route planning and seat-revenue maximizing. Almost overnight, they're flying. ${ }^{.17}$

112. See LoPucki, supra note 12, at 85-89.

113. See id. at 80-85.

114. See White, supra note 8 , at 1387.

115. See id. at 1385.

116. See LoPucki, supra note 1, at 86 n.362. 87 n.366

117. Ralph T. King Jr.. The Virual Compans. When Is a Compans Not a Compans' When It's in a Box, WALL ST. J., Nov. 14, 1994, at R12. 
Because the virtual company does not own the resources it commandeers, it is born judgment proof. Even if it is highly profitable, a liberal dividend policy will keep it judgment proof without running afoul of the law.

Alternatively, a virtual company can take on the role of a company that owns things, but does not do things. Sara Lee was recently hailed by the Wall Street Journal as the first virtual company. ${ }^{118}$ Sara Lee plans to outsource the manufacturing of its products and become merely a distributor. To accomplish that, the company is selling its manufacturing operations. ${ }^{119}$ That move alone will not relieve Sara Lee of liability for its products. But it would be only a short step further for Sara Lee to contract for the sale and distribution of its products by others. Sara Lee's sole assets would then be the trademarks and contract rights. The new Restatement (Third) of Torts makes clear that such a company would not be liable to purchasers of products bearing the company's trademark provided that the company did not participate substantially in the design, manufacture, or distribution of the product. ${ }^{120}$ The no-name subcontractors who manufactured and distributed for Sara Lee could judgment proof themselves to the limit of the law, without concern for public relations. They would be invisible to Sara Lee's customers in the ordinary operation of the business, just as was the franchisee in Mobil Oil v. Bransford. ${ }^{121}$ They would emerge from the shadows only to show their empty pockets in litigation. Neither Sara Lee nor its subcontractors would have to pay products liability claims. ${ }^{122}$

The specter of judgment proofing and the specter of the virtual company are one and the same, and the specter is advancing. White's rallying cry, "Liability lives," 123 remains accurate. But for how long?

118. See Lowenstein, supra note 1.

119. See id.

120. See RESTATEMENT (THIRD) OF TORTS: PROduCtS LIABILITY $\$ 14 \mathrm{cmt}$ d (Proposed Final Draft 1997) (stating that "the [trademark] licensor, who does not sell or otherwise distribute products, is not lable under this Section of this Restatement"); Yoder v. Honeywell Inc., 104 F.3d 1215, 1222-24 (10th Cir. 1997) (holding a parent company not liable for defective products manufactured and soid by its subsidiary under the trademark of the parent company).

121. 648 So. 2d 119 (Fla. 1995); see supra text accompanying notes 36-37.

122. This does not necessarily mean that Sara Lee or its subcontractors would be any less concerned with the quality of their products. They would still have to sell them and maintain the good will of the customers who buy them.

123. White, supra note 8 , at 1412 . 